\title{
Mid storage seed hardening: a mechanical method to maintain seed viability during long term jute seed preservation
}

\author{
Md. Nasir Uddin ${ }^{1}$, S. M. Mahbub Ali ${ }^{1}$, Md. Abu Sadat ${ }^{2 *}$, Md Amzed Hossain Chowdhury ${ }^{3}$, Israt Jahan \\ Mumu $^{4} \&$ Md. Zablul Tareq ${ }^{2}$ \\ ${ }^{1}$ Genetic Resources and Seed Division, Bangladesh Jute Research Institute, Dhaka-1207, Bangladesh \\ ${ }^{2}$ Basic \& Applied Research on Jute project, Bangladesh Jute Research Institute, Dhaka-1207, Bangladesh \\ ${ }^{3}$ Department of Agricultural Extension, Titas, Cumilla, Bangladesh \\ ${ }^{4}$ Department of Genetics and Plant Breeding, BSMRAU, Gazipur, Bangladesh \\ *Email: sadat@snu.ac.kr
}

\section{ARTICLE HISTORY}

Received: 16 August 2020

Accepted: 27 October 2020

Published: 01 January 2021

KEYWORDS

Jute seed

Oil content in seeds

Seed hardening

Seed health

Seed storage

Seed viability
ABSTRACT

Seed plays an important role in agricultural sector for both production and consumption purpose. Availability of vigour seed is one of the major constraints for maximizing crop production. However, healthy seed can also lose its viability during seed storage by changing different physio-chemical properties. Influence of environmental factors and seed containers during storage leading to seed deterioration. In this research, mid storage seed hardening treatment was applied in different aged seeds of jute species (C. Capsularis \& C. olitorius) with two types of storage bags. Seed hardening treatment showed the less moisture content with better germination percentage compared to the untreated species of jute seeds. Seed packing in polythene bags during both short and long term seed storages had higher viable seeds compared to the cloth packing seeds. The effect of seed hardening treatment on seed oil content and pattern of oil degradation is distinct in early period of storage. The faster rate of oil degradation, soluble protein and free amino acids was found in seeds of un-treated stored seeds in cloth bag. Contrary, very slow rate of oil degradation was observed in harden seed and stored in polythene bag which indicated better storability of harden seeds.

\section{Introduction}

Main purpose of seed storing is to use seed for the next cropping season. Physiologically mature seeds are considered to have maximum viability but storage causes loss of viability leading to seed death (1). In storage, seed deterioration is a common process that occurs in all seeds (2). In the seed deterioration process different physiological and biochemical modification arises in naturally aged seeds. Among biochemical modifications, lipid peroxidation is remarkable which is enhanced in stored seed that negatively affect the seed viability (3). Lipid peroxidation is associated with the chemical modification of lipid reserves in stored seeds resulting from the production of free fatty acids in oil rich seeds due to high susceptibility to peroxidation $(4,5)$.

Maintaining seed moisture content, storage temperature and storage period can lead to preserve the long term seed viability (2). Mid storage seed hardening treatment is a process which is used to improve the seed viability during long term seed storage of different seeds (6). However, mid storage seed hardening technique is more effective for the seeds having little and medium vigour. The reason behind this is to permit the stored seeds to absorb moisture up to $30 \%$ (wet basis) for certain protective, curative or restorative operation followed by drying and re-storage (7). In addition, storage containers of seeds also had significant involvement to keep seed alive and vigour during long term seed storage (8).

Mid storage seed treatment includes removal of inhibitors and toxic metabolic byproducts from seed, seed germination advancement, reduced moisture uptake by treated seeds and counteraction of lipid peroxidation reactions $(9,10)$. Although, seeds of a good number of cereals, oil seeds, vegetables and flowers so far tested and responded very well to mid storage seed hardening (11-13), but physiology of mid

(c) Uddin et al (2021). This is an open-access article distributed under the terms of the Creative Commons Attribution License, which permits unrestricted use, distribution and reproduction in any medium, provided the original author and source are credited (https://creativecommons.org/licenses/by/4.0/).

To cite this article: Uddin M N, Mahbub Ali S M, Sadat M A, Chowdhury M A H, Mumu I J, Tareq M Z. Mid storage seed hardening: a mechanical method to maintain seed viability during long term jute seed preservation. Plant Science Today. 2021;8(1):79-88. https://doi.org/10.14719/pst.2021.8.1.916

Plant Science Today, published by Horizon e-Publishing Group, is covered by Scopus, Web of Science, BIOSIS Previews, Clarivate Analytics, etc. Full list at http://www.plantsciencetoday.online 
storage hardening in the maintenance of viability of jute seed is yet to be determined. Only a few experiments were conducted to observe the effect of different storage containers with some chemicals (6, 8).

Jute is an important traditional cash crop of Bangladesh accounting 6\% of the foreign earnings through exports $(14,15)$. In Bangladesh two jute species (Corchorus capsularis L. and Corchorus olitorius L.) are commonly cultivated (16). Jute cultivation area was decreased in last two decades due to the importance of food crops however, area under jute cultivation was increased in last few years indicating the prospects of jute in Bangladesh (17). Availability of quality seed with cultivable land is the main constraints for profitable jute production. Bangladesh Agricultural Development Corporation (BADC) provides only $10-15 \%$ of the required jute seed every year (18). The remaining seeds are managed locally, stored by the farmers but the quality is questionable due to the seed storage condition (19).

To fulfil the demand, jute seeds are imported from the neighboring countries every year and the qualities of those imported seeds have no guarantee $(15,20)$. Moreover, jute seed lost the viability during long term storage. To avoid the loss of jute seed, an experiment was conducted through the mid storage treatments and found significant improvements in both seed physiology and chemical composition.

\section{Materials and Methods}

Different aged seeds (fresh seed, three months old seed, six months old seed, nine months old seed and twelve months old seed) of jute varieties were collected form the Jute Agriculture Experimental Station, Jagir, Manikganj, Bangladesh and seeds were stored in ambient condition to allow deterioration. Mid storage seed hardening treatments were applied at the starting of storing seed, six months after storing and after one year of storing by $6 \mathrm{hrs}$ hydration. Hardened seeds were wrapped by using two different packaging goods viz. hermetically closed polythene packet (thickness $8 \mu$ ) and cloth bag which stored at natural condition. Each polythene packet and cloth bag contained 100 gm jute seed. Polythene packets were closed by sealing machine and cotton thread was used to tight cloth bags (Supplementary Fig. S1).

\section{Environmental condition of store}

Maximum and minimum temperature and relative humidity of ambient condition were recorded daily from February 2009 to March 2011 and averaged monthly. The temperature and relative humidity experienced by one year aged seeds in ambient condition are illustrated in Supplementary Fig. S2.

\section{Design of the experiment}

The laboratory experiment was done in factorial Complete Randomized Design (CRD) with four replications.

\section{Seed quality assesment}

One packet of jute seed of each treatment was picked up randomly from the store at three different time of seed storing and seeds were hardened by $6 \mathrm{hrs}$ hydration. The harden and controlled seeds of each treatment were subjected to different qualitative tests such as content of moisture, thousand seed weight, percentage of germination, Index of seedling vigour, electrical conductivity test and mean germination time.

\section{Moisture contents}

Seed moisture was measured by oven-dry method. The moisture content percentage of the seed was done by the following formula (http://seednet.ap.nic.in/Stl/htmlpages/seedmoisturetesting.htm):

$\left(\mathrm{m}_{2}-\mathrm{m}_{3}\right)$

Moisture content $(\%)=\longrightarrow 100$

$\left(\mathrm{m}_{2}-\mathrm{m}_{1}\right)$

Where,

$\mathrm{m}_{1}=$ weight of crucible + lid

$\mathrm{m}_{2}=$ weight of crucible + lid + fresh seed

$\mathrm{m}_{3}=$ weight of crucible + lid + dried seed

\section{Seed weight}

Thousand jute seed was counted manually from the pure seed and their weight was recorded by using an electronic balance.

\section{Germination test}

One hundred normal seeds of every treatment combination was placed in petridish on soaked filter paper with distilled water. Four petridishes was used for each test. The petri dishes were put in germinator at $30{ }^{\circ} \mathrm{C}$ in dark condition for 5 days. Every day seedlings were counted up to the finalization of germination at fifth day. A seed was treated to be germinated if the seed coat ruptured and radicle having up to $2 \mathrm{~mm}$ length. Germination percentage was estimated using the following formula (21).

Germination $(\%)=\frac{\begin{array}{c}\text { Number of seeds } \\ \text { germinated }\end{array}}{\begin{array}{c}\text { Number of seeds } \\ \text { tested }\end{array}} \times 100$

\section{Seedling vigour index}

Ten seedling from each petridish were uprooted on the fifth day of the germination experiment and dried at $70{ }^{\circ} \mathrm{C}$ for $72 \mathrm{hrs}$ for dry matter analysis. Fresh weight and dry weight of those samples were measured. Seedling vigour index was estimated by the following formula (22).

\section{Seedling vigour index $=$ Germination $(\%) \mathrm{x}$ Total seedling dry matter}

\section{Electrical conductivity test}

For testing electrical conductivity, 2 gm seeds of individual sample was taken in a conical flask having $50 \mathrm{ml}$ de-ionized water and were incubated at $20{ }^{\circ} \mathrm{C}$ for $20 \mathrm{hrs}$ (21). After $20 \mathrm{hrs,} \mathrm{electrical} \mathrm{conductivity} \mathrm{of}$ the decanted water containing seed leachate was estimated with a conductivity meter (Model-CM30ET). Four replicates of measurements were made for individual sample of seed. 


\section{Determination of chemical composition of seed}

The harden and control seeds of both storage containers were crashed through a mini grinding mill and this smashed seed samples were used to estimate the chemical composition of seed. Total soluble protein, total free amino acid, total soluble sugar and oil content were determined at every 3 months interval up to 12 months.

\section{Total soluble protein estimation}

For estimating total soluble protein, seed extracts were processed through a previously described method (23). A standard protocol was used to estimate the total soluble proteins (24). For total soluble protein estimation one hundred $\mathrm{mg}$ of jute seed powder was used. Optical density was measured by a double beam spectrophotometer (Model: HITACHI 200-20, Japan) having $660 \mathrm{~nm}$ wave length. And the total soluble protein was measured as $\mathrm{mg} \mathrm{g}^{-1}$ fresh weight by using the standard curve.

\section{Total free amino acid estimation}

Total free amino acids of both treated and control seeds were estimated according to the standard method (25). In this method, hundred mg jute seed powder was used to estimate total free amino acid. The optical density was measured by using a double beam spectrophotometer (Model: HITACHI 200-20, Japan) having $570 \mathrm{~nm}$ wave length. Total free amino acid was measured as $\mathrm{mg} \mathrm{g}^{-1}$ fresh weight by using the standard curve.

\section{Total soluble sugar estimation}

Anthrone-sulphuric acid method was used to quantified total soluble sugar content from the seeds (26). One hundred mg of jute seed powder was used to estimate the total soluble sugar. Absorbance was measured by using double beam spectrophotometer (Model: HITACHI 200-20, Japan) at $630 \mathrm{~nm}$ wave length. And finally the sugar content was estimated as $\mathrm{mg} \mathrm{g}^{-1}$ fresh weight using standard curve.

\section{Oil content estimation}

Moisture free seed meal was used to determine the oil percentage through solvent extraction by using other petroleum ether (boiling point $60{ }^{\circ} \mathrm{C}$ to $80{ }^{\circ} \mathrm{C}$ ) in a Soxhlet apparatus for eight hrs (27). Moisture free seed meal was prepared by pre-dried (60 $\left.{ }^{\circ} \mathrm{C} ; 24 \mathrm{hrs}\right)$. Oil estimation was done by using 2 gms of dried seed meal. After eight hrs of refluxing no oil was found from the residue.

\section{Statistical analysis}

Statistical analysis of the data was done by analysis of variance (ANOVA). Microsoft EXCEL and MSTAT software programs were used wherever appropriate. Correlation and regression analysis was done to find out the functional relationships among the parameters.

\section{Results}

\section{Physical changes of stored jute seeds}

\section{Changes in seed moisture}

In present study, initial moisture content of jute seed varied from 8.3 to $8.7 \%$ and 8.2 to $8.5 \%$ in $C$. capsularis and $C$. olitorius respectively (Fig. 1). Mid storage seed hardening did not affect the seed moisture content in both species of fresh jute seed. Moisture content of jute seeds were increased after the seed storage and moisture contents of stored seeds in cloth bags were prominent over polythene bags. Moisture content of jute seeds in cloth bags fluctuated in different months of the year but in polythene bags were almost steady after three months of storing. Rapid increase in seed moisture content in cloth bag under ambient condition was
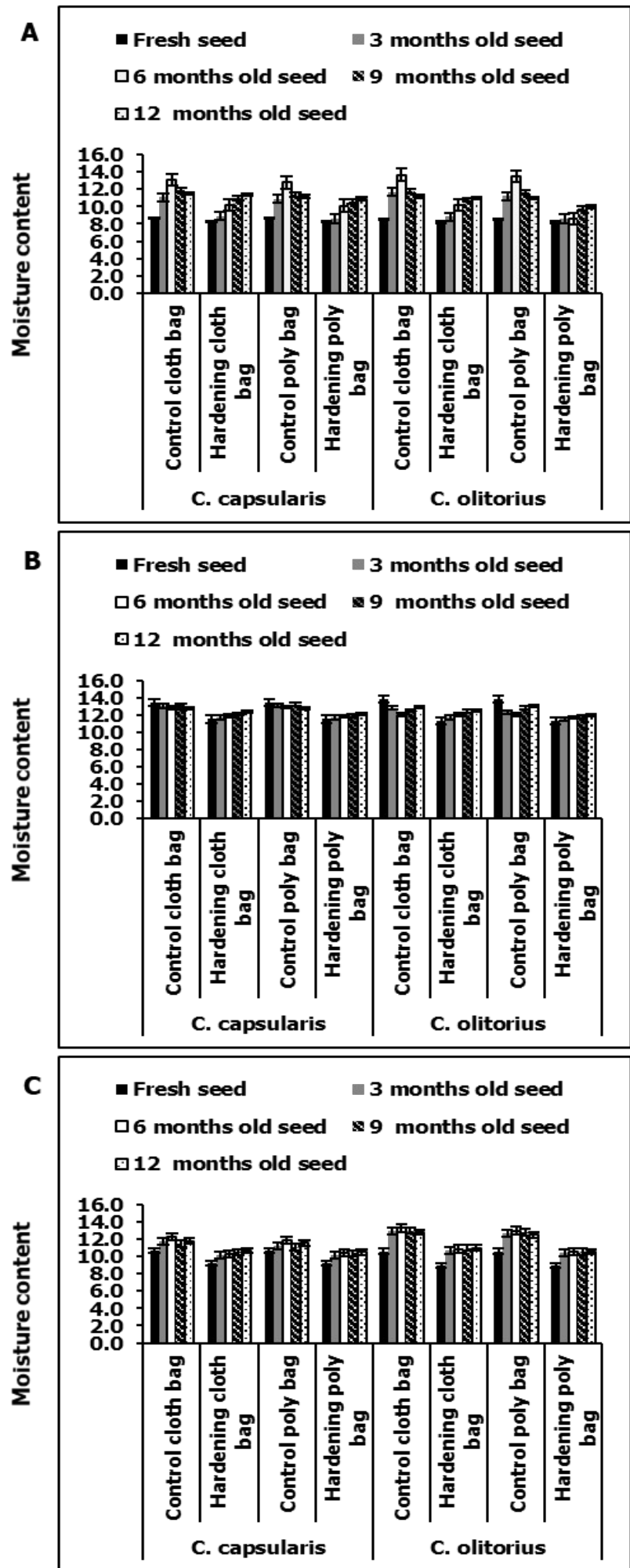

Fig. 1. Moisture content of different aged jute seed with seed containers. A: seed hardening during initial stage of seed storing B: seed hardening during six months after seed storing, C: seed hardening during one year after of seed storing. 
attributed due to increase of relative humidity at the atmosphere (Supplementary Fig. S3).

\section{Changes in seed weight}

After hardening, seed weight of different aged jute seeds kept in polythene and cloth bag and data were analysed. After one year of storage of different aged jute seed, thousand seed weight ranged from $3.1 \mathrm{gm}$ to $3.5 \mathrm{gm}$ and $1.7 \mathrm{gm}$ to $2.0 \mathrm{gm}$ in $C$. capsularis and in C. olitorius respectively (Table 1 ). Seed weight of $C$. capsularis jute was higher than $C$. olitorius seed due to its larger size. Analysis found very little reduction in thousand seed weight after mid storage seed hardening treatments in both containers. In the case of $C$. olitorius seed, no significant difference was observed after seed hardened in different periods of seed storing in both containers. However, seed weight of untreated seed in cloth bag was little increased in 3 months and 9 months storing compared to the hardened seed in cloth bag for $C$. capsularis seed (Table 1). found from harden seeds (63\%) after one year storage of fresh $C$. capsularis jute seed (Fig. 2 C) and the lowest (1\%) was in control of 12 month naturally aged seed. In $C$. olitorius jute seed, hardening treatment improve the seed quality up to 6 month naturally aged seed (Fig. 2 C). The results clearly showed that it is not possible to improve the germination ability of healthy seeds but low vigour seed can be improved by mid storage seed hardening.

\section{Changes in vigour index}

Changes in vigour index correlated to the seedling dry weight where seedling vigour decreased considerably after 12 months of storage (Table 2). Among the two species of jute, $C$. capsularis showed higher vigour index than $C$. olitorius seed. Immediately after seed hardening of $C$. capsularis seed, seedling vigour index was 145.4 in polythene bag and 23.80 in cloth bag after one year storage. On the other hand, seedling vigour index of harden $C$. olitorius jute seed in polythene bag was 80.82 and in

Table 1. Changes in 1000 seeds weight (g) of different aged seed of $C$. capsularis and $C$. olitorius jute seed after one year storage.

\begin{tabular}{|c|c|c|c|c|c|c|c|c|c|c|c|}
\hline \multirow{3}{*}{ Treatments } & \multirow{3}{*}{$\begin{array}{c}\text { Seed } \\
\text { container }\end{array}$} & \multicolumn{10}{|c|}{ Seed age (Month) } \\
\hline & & \multicolumn{5}{|c|}{ C. capsularis seed } & \multicolumn{5}{|c|}{ C. olitorius seed } \\
\hline & & Fresh & 3 months & 6 months & 9 months & 12 months & Fresh & 3 months & 6 months & 9 months & 12 months \\
\hline Hardening & Cloth bag & $3.2 \mathrm{a}$ & $3.2 \mathrm{a}$ & $3.2 \mathrm{a}$ & $3.2 \mathrm{a}$ & $3.0 \mathrm{a}$ & $1.9 \mathrm{a}$ & $1.9 \mathrm{a}$ & $2.0 \mathrm{a}$ & $1.9 \mathrm{a}$ & $1.7 \mathrm{a}$ \\
\hline Control & \multirow{2}{*}{-Poly bag } & $3.3 \mathrm{a}$ & $3.2 \mathrm{a}$ & $3.2 \mathrm{a}$ & $3.3 \mathrm{a}$ & $3.3 \mathrm{a}$ & $1.9 \mathrm{a}$ & $1.9 \mathrm{a}$ & $1.9 \mathrm{a}$ & $1.9 \mathrm{a}$ & $1.9 \mathrm{a}$ \\
\hline Hardening & & $3.2 \mathrm{a}$ & $3.2 \mathrm{a}$ & $3.2 \mathrm{a}$ & $3.0 \mathrm{a}$ & $3.1 \mathrm{a}$ & $1.9 \mathrm{a}$ & $1.8 \mathrm{a}$ & $1.8 \mathrm{a}$ & $1.8 \mathrm{a}$ & $1.8 \mathrm{a}$ \\
\hline
\end{tabular}

*values in columns followed by the same letter are not significantly different, $\mathrm{P} \leq 0.05$, LSD.

Table 2. Changes in seedling vigour index of different aged seed of $C$. capsularis and $C$. olitorius jute seed after one year storage.

\begin{tabular}{|c|c|c|c|c|c|c|c|c|c|c|c|}
\hline \multirow{3}{*}{ Treatments } & \multirow{3}{*}{$\begin{array}{c}\text { Seed } \\
\text { container }\end{array}$} & \multicolumn{10}{|c|}{ Seed age (Month) } \\
\hline & & \multicolumn{5}{|c|}{ C. capsularis seed } & \multicolumn{5}{|c|}{ C. olitorius seed } \\
\hline & & Fresh & 3 months & 6 months & $\begin{array}{c}9 \\
\text { months }\end{array}$ & $\begin{array}{c}12 \\
\text { months }\end{array}$ & Fresh & 3 months & 6 months & 9 months & 12 months \\
\hline Hardening & Cloth bag & $23.8 \mathrm{c}$ & $22.3 \mathrm{c}$ & $39.8 \mathrm{~b}$ & $22.5 \mathrm{a}$ & $9.7 \mathrm{a}$ & $27.1 \mathrm{c}$ & $21.5 \mathrm{~b}$ & $18 . b$ & $12.2 \mathrm{a}$ & $5.0 \mathrm{a}$ \\
\hline Control & \multirow{2}{*}{ Poly bag } & $126.2 \mathrm{~b}$ & $63.0 \mathrm{~b}$ & $14.3 \mathrm{c}$ & $4.0 \mathrm{~b}$ & $2.9 \mathrm{~b}$ & $62.9 \mathrm{~b}$ & $11.6 \mathrm{c}$ & $1.0 \mathrm{c}$ & $1.0 \mathrm{c}$ & $1.0 \mathrm{~b}$ \\
\hline Hardening & & $145.4 \mathrm{a}$ & $109.3 \mathrm{a}$ & $89.5 \mathrm{a}$ & $22.9 \mathrm{a}$ & $10.2 \mathrm{a}$ & $80.8 \mathrm{a}$ & $66.2 \mathrm{a}$ & $42.1 \mathrm{a}$ & $5.0 \mathrm{~b}$ & $4.0 \mathrm{a}$ \\
\hline
\end{tabular}

*values in columns followed by the same letter are not significantly different, P $\leq 0.05$, LSD.

\section{Changes in seed germination}

Germination percentage of fresh and naturally aged jute seeds after hardening treatments were shown in Fig. 2. Significant differences were observed in germination percentage between jute species, seed age, containers and hardening. Germination percentage of fresh $C$. capsularis jute seeds was $95 \%$ and it reduced to $54 \%$ after one year storage while 12 month naturally aged seed dropped to $4 \%$ in the same storage period (Fig. 2 A). In C. olitorius jute seed, germination percentage of fresh seed was $96 \%$ and it reduced to $41 \%$, whereas 12 month naturally aged seeds germination was only $1 \%$ after one year of storage (Fig. 2 A). Comparing between two storage containers, germination percentage reduced from 95 to $78 \%$ in poly bag and this viability reached to $29 \%$ in cloth bag of $C$. capsularis seed (Fig. 2 B). In $C$. olitorius jute seed, polythene bag maintained $75 \%$ viability after one year storage (Fig. 2 B). Contrary in cloth bag, germination percentage was almost zero after 6 months storage which indicated that jute seed storing in cloth bag is not safe for maintaining viability in storage. The highest germination was cloth bag it was zero. Hardening of 12 month naturally aged jute seed of $C$. capsularis showed a certain level of seedling vigour index in both storage containers. Contrary in $C$. olitorius jute seed, over 18 month aged seed didn't show any vigour index. The rate of decrease in vigour index was more pronounced in the seed of $C$. olitorius in cloth bag seed than in the seed of $C$. capsularis in polythene bag.

\section{Changes in leachate conductivity}

The leaching of solutes from the imbibed seed increased with the increase of storage period as it is exhibited by the increase of electrical conductivity of seed electrolytes (Fig. 3). This is a general indication of seed deterioration with passing of storage time. Seed deterioration was faster in the seeds of cloth bag at ambient condition as it showed the highest electrical conductivity than polythene bag. Faster seed deterioration in cloth bag at ambient condition was attributed to higher seed moisture content (Fig. 1) as well as increase of storage temperature. The reverse is true in the case of seeds in airtight 

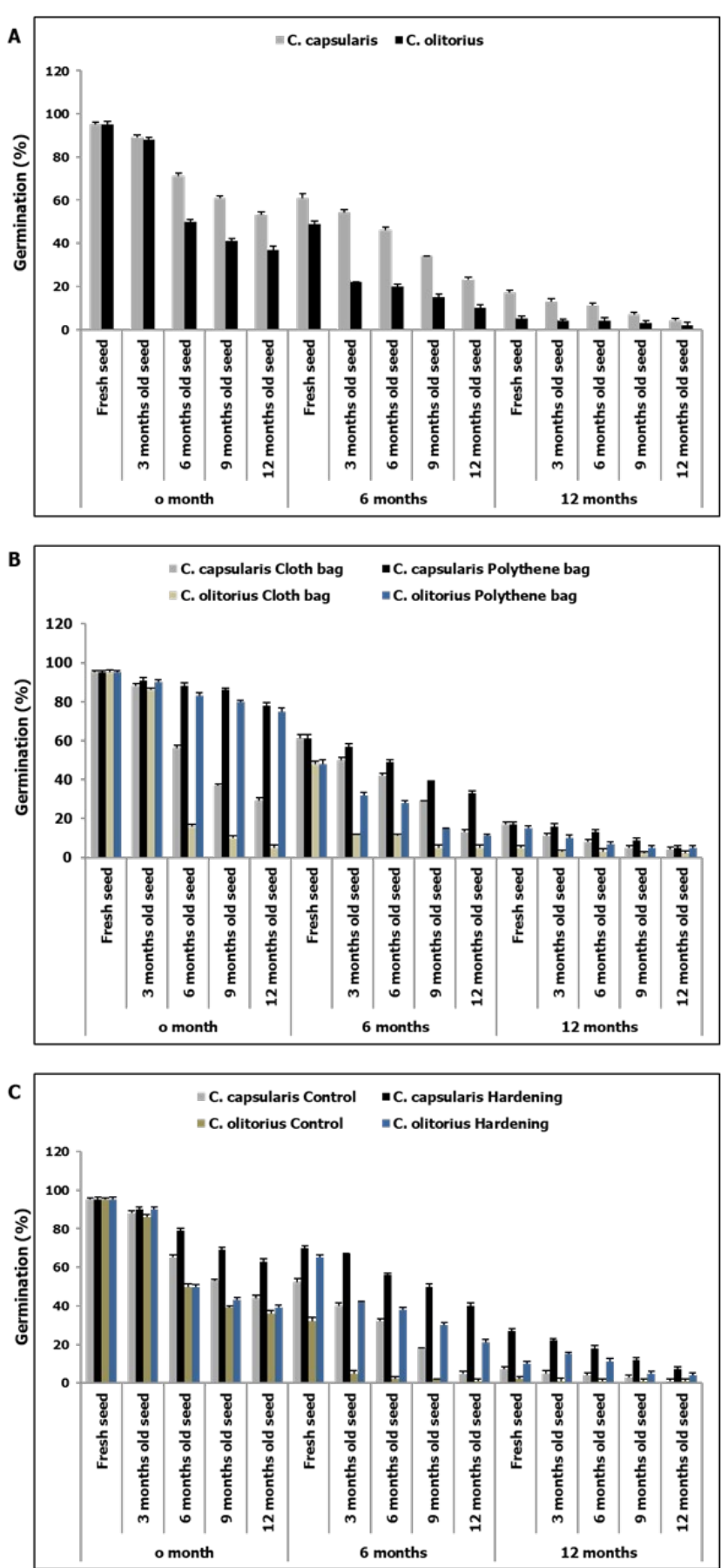

Fig. 2. Germination rate of different aged jute seed along with seed containers. A: seed germination rate of $C$. capsularis and $C$. olitorius in ambient condition, B: seed germination rate of $C$. capsularis and $C$. olitorius seed stored in different containers, C: seed germination rate of $C$. capsularis and $C$. olitorius seed stored after seed hardening treatments.

polythene bag which effectively resist water vapour exchanges.

\section{Biochemical changes of stored seed Changes in soluble protein}

The total amount of soluble protein in jute seed reduced with the increase of storage period irrespective of container and seed hardening. In general, decrease rate of soluble protein was higher in of $C$. capsularis seed than $C$. olitorius seed (Fig. 4). The decrease rate of soluble protein was very lower in different aged seeds stored in polythene bag than that of cloth bag over the 12 months storage. Seed hardening treatment increase the amount of total
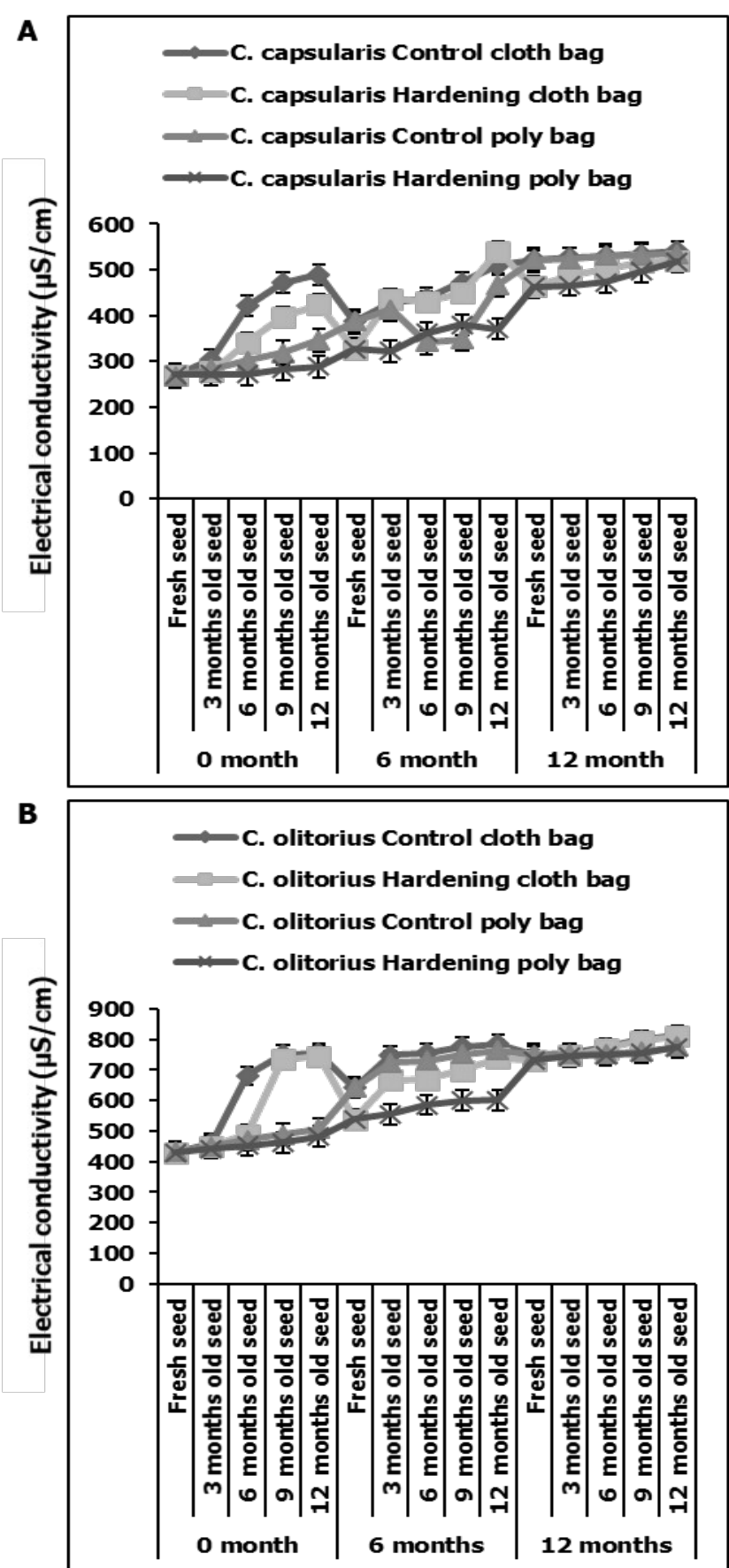

Fig. 3. Effect of seed hardening on the electrical conductivity of different age of seeds from C. capsularis (A) and C. olitorius (B) jute seeds over the storage period.

soluble protein of both the varieties, however seeds in the polythene bags were prominent over cloth bags.

\section{Changes in free amino acid}

The amount of total free amino acids in both treated and untreated seeds was found to increase with the increase of storing periods in both the species (Fig. 5). Increase of free amino acid was more pronounced in seed of cloth bag stored at ambient condition while it was minimum in harden seeds kept in poly bag. The rate of increase in free amino acid peaked up after 6 months storing in most of the storing environments which indicated that jute seed become very susceptible to protein degradation at this time. Increase of free amino acid is the resultant of 

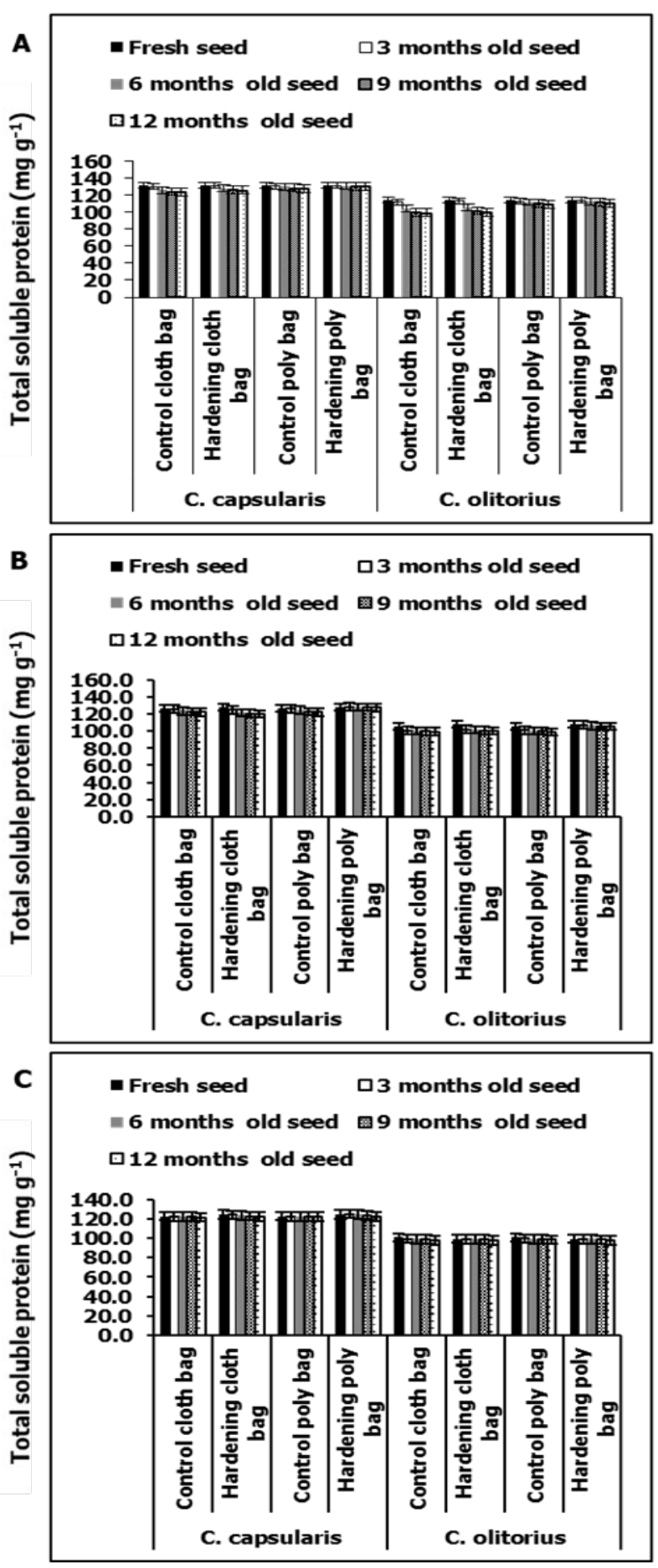

Fig. 4. Interaction effect of seed hardening and storage container on the soluble protein of $C$. capsularis and $C$. olitorius jute seeds over the storage period. A: seed hardening at initial stage of seed storing, B: seed hardening at six months after seed storing, C: seed hardening at one year after of seed storing.

decrease in protein content as there is strong negative relationship between total soluble protein and total free amino acid, which indicated that amount of free amino acid increased with the decrease of soluble protein.

\section{Changes in soluble sugar}

Soluble sugar contents in two species of jute seed decreased with the progress of storage period in seeds of all aged. In case of seed hardening, seeds in the polythene bags had the highest soluble sugar in both the species of jute seeds (Fig. 6). Untreated
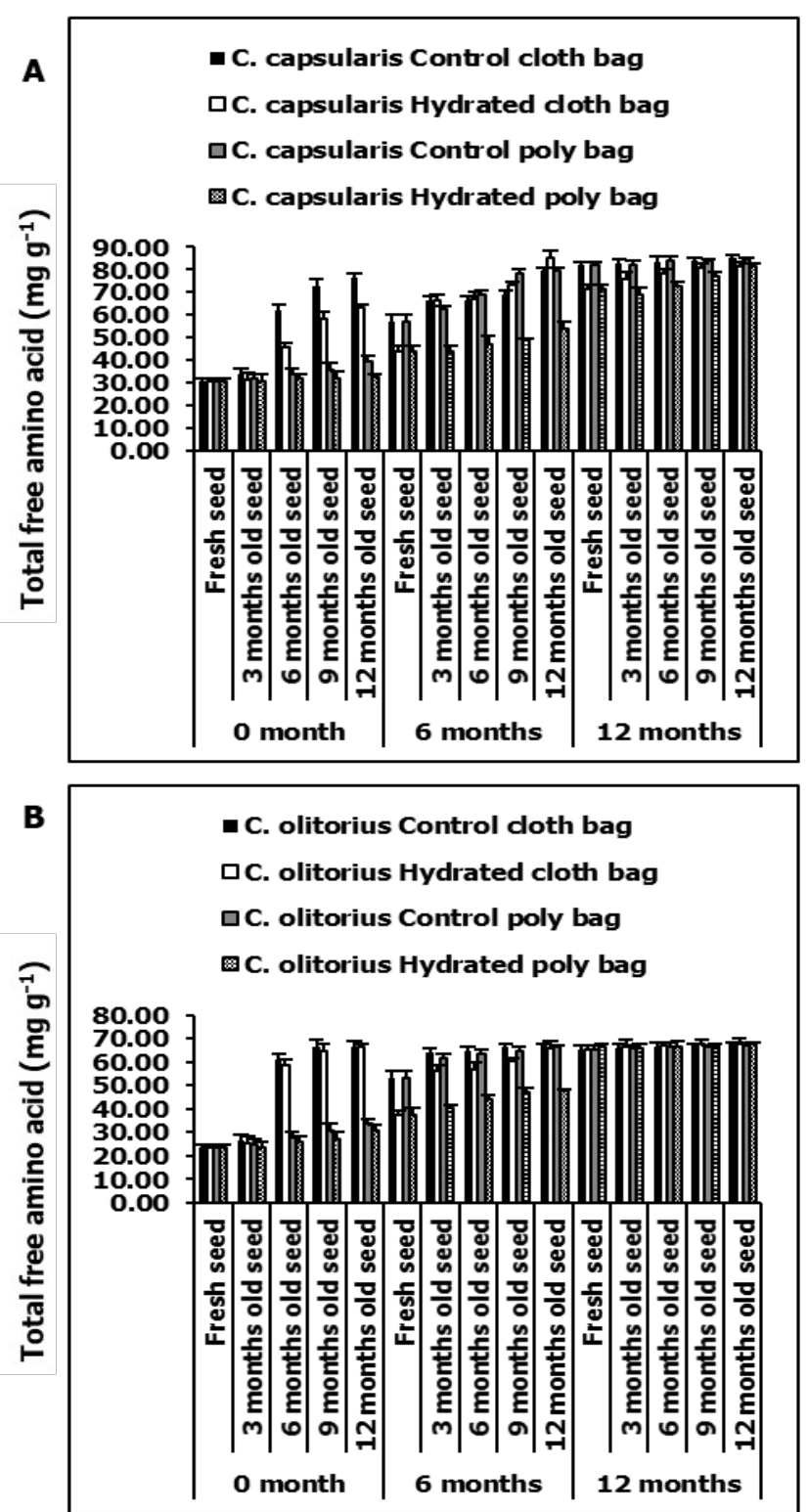

Fig. 5. Interaction effect of seed hardening and storage container on the total free amino acid of naturally aged seed of C. capsularis (A) and C. olitorius (B over the storage period and different seed hardening periods.

jute seeds in polythene bags showed the $2^{\text {nd }}$ higher soluble sugar followed by the seeds of the untreated and hardened seeds in the cloth bags. This observation was found in the fresh seed, three months old and six months old seed of both the species.

\section{Changes in oil content}

Oil content amount of stored jute seed was decreased with the increase of storing period for all aged seeds of both jute species (Fig. 7). The rapid decline of oil content was found in seeds stored in cloth bag and the amount was comparatively slower in seeds stored in polythene bag followed by hardened seed in the polythene bags and untreated cloth bags. These results clearly indicating that aging of seed cause deterioration of seed health leading to poor seed germination rate compare to the germination of fresh healthy seeds of jute. 

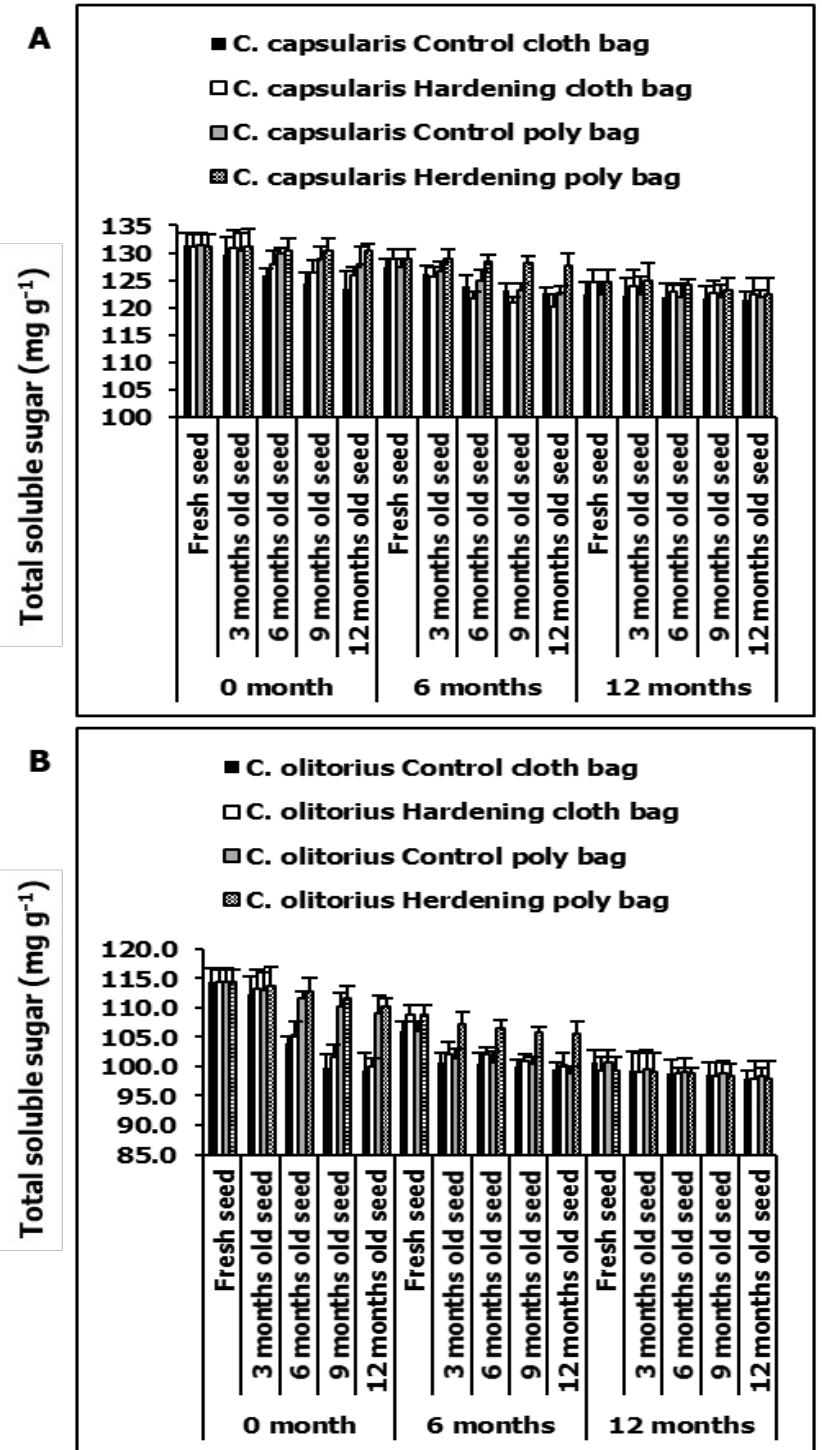

Fig. 6. Interaction of seed hardening and storage container on the total soluble sugar of naturally aged seed of $C$. capsularis (A) and $C$. olitorius (B over the storage period and different seed hardening periods.

\section{Discussion}

Moisture content of untreated seeds in both containers was found comparatively higher than the treated seeds of both jute varieties in fresh and naturally aged seeds. The moisture contents of untreated seeds in the polythene bags were increased in first three months and remain stable in six, nine and twelve month's storage (Fig. 1). Similar to the moisture content, thousand seed weight of both jute species of all aged seeds were changed remarkably (Table 1 ). Proper moisture content and seed weight is one of the most important indicators for the good quality of seeds. Seed moisture content is directly related to relative humidity of the atmosphere and seed weight also depends on the moisture absorption from the environment $(28,29)$. Storage of seed changes different physical and chemical properties of seed during long term storage, however short term seed storage had no effect on seed germination and seedling growth (30). The higher rate of respiration is related to the loss of reserve nutrient of seed leading to reduced the seed weight considerably from cloth bags at ambient condition (31).
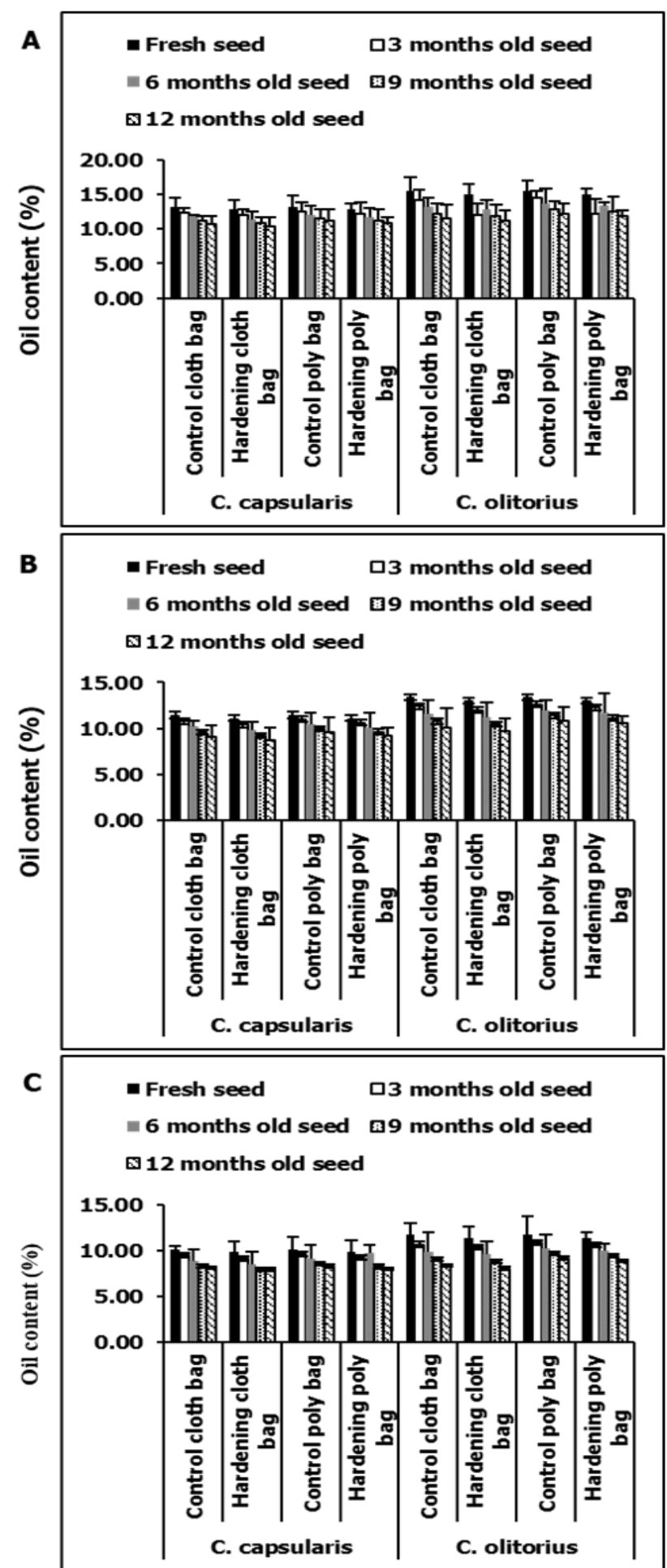

Fig. 7. Interaction of seed hardening and storage container on oil content of of naturally aged seed of $C$. capsularis (A) and $C$. olitorius (B over the storage period and different seed hardening periods.

Storage duration and storage container reduced the percentage of seed germination in both the species of jute seed (Fig. 2). In addition, cloth bag showed the lower percentage of seed germination compared to the polythene bags. This result indicated that seed viability is highly depended on the storage container and similar results were also found in cotton seed storing (32). It was found that applying mid storage seed treatment improve the germination percentage (Fig. 2). Mid storage seed hardening is highly effective in retaining vigour and viability in 
storage as it removes metabolic toxic substances through activation of cellular detoxifying enzymes during the hydration phase of seed hardening (33). Improvement in seed viability in mid storage hardening also occur due to repair of vital bioorganelles by an endogenous enzymatic restorative system in the hydrated seeds which is primarily prophylactic in nature rather than curative $(34,35)$.

The pattern of leachate conductivity differed widely between two storage containers, age of jute seeds due to seed mid storage seed hardening (Fig. 3). In general, leachate conductivity was the highest in control treatment in the seeds of cloth bag of both jute varieties. Leachate conductivity decreased considerably in harden seeds of polythene bag which might be due to improvement in membrane integrity due to mid storage seed hardening. A repair of damage of bio membranes would bring about a permanent change resulting in a significant lowering of electrical conductance of seed leachate immediately after hardening treatment. Hardening treatment showed much lower conductance than the corresponding control after natural ageing, indicating the prophylactic nature of mid storage treatment (8). The present study revealed that leaching of electrolytes from seed stored in different containers was negatively correlated with seed germination. Similar result was found in okra, carrot and onion seeds where leakage of electrolytes as increase in electrical conductivity decreased germination of stored seeds (36).

Soluble protein declining rate of jute seed can be occurred due to fluctuations in protein synthesis rate, or protein degradation rate or both during storage of seeds (24). Activity of proteinase may associate with the rate of declining of soluble protein. The activity of malate dehydrogenase, peroxidase and catalase has an important role in protein degradation and maintenance of stored seed. (37). Degradation of soluble protein can also be resulted from reactive oxygen species (ROS) action, that can abolish enzyme activities and the content of late embryogenesis abundant (LEA)- like proteins or small heat shock proteins (sHSP) that play a significant role in maintaining long storage life of dry seeds (38). In the present study, seeds in cloth bags showed higher protein degradation (Fig. 4) which might be ascribed due to the increase of respiratory enzymes at higher relative humidity and higher temperature under ambient storage environment. Similar results were also reported in cotton seed preservation (39).

The increase of free amino acid accompanied by the decreasing of seed protein contents in the storage probably due to greater degradation of proteins by the activity of proteinases (24). The changes in protein and amino acid in jute seed during the storage periods also confirmed the results found in two crops such as maize and groundnut $(40,41)$. Amount of soluble protein and free amino acid in seeds also indicated the level of viability as strong positive correlation was observed between total soluble protein and germination and strong negative correlation between total free amino acid and germination (Fig. 5). This indicated that decrease in viability and germination of jute seed is associated with degradation of total soluble protein and increase of total free amino acid.

Decline in total soluble sugar was minimal in harden seeds while it was pronounced in the seeds in the cloth bag (Fig. 6). Which might be associated to higher temperature and relative humidity prevailed in ambient environment causing reduction of carbohydrates reserve for supporting elevated respiratory metabolism in storage (42). In general, total soluble sugar decline with increase of seeds age due to limited respiratory substrate (42, 44). Another possibility of soluble sugar decline is the depletion of disaccharides due to unable to protect sugars on structural integrity of membranes or a noncrystalline liquid state of high viscosity (45-47). Similar results were also observed in Pinnus sp., maize seeds and also in different cereal seeds (48-51). Changes in soluble sugar have great implication in seed viability as it indicated through positive relationship between germination percentage and total soluble sugar. This might be due to the existence of reducing sugars which may lead to deterioration of protein components by Amadori and Maillard reactions. These are non-enzymatic carbonyl amine reactions preferentially take place in dry systems contributing seed deterioration in storage $(52,53)$. The decrease amount of oil content in jute seed was related to the lipid peroxidation which has been considered as the major causes of seed degradation in seeds having oil dominating characters (5). Highly reactive free radicals intermediates, lipid hydroperoxides and different secondary products are produced from the lipid peroxidation that potentially can destruct cell membrane, enzymes and nucleic acids and finally reduces viability of seed (33). In the present study, higher rate of decreasing oil content in seeds in the cloth bag was observed (Fig. 7) and similar decreasing trend of oil content was found in cotton seed stored in polythene bag and cloth bag (40). This was might be ascribed to faster deterioration of that biochemical under the condition of broad temperature variation and high relative humidity under ambient under seed storing condition (54).

\section{Conclusion}

The effect of seed hardening on different physical and chemical properties is distinct in different periods of storage during the periods of experiment. Seed hardening treatment maintain the seed health compared to the untreated seeds of different ages however; mid storage seed hardening is very efficient for low or medium vigour seeds compared to fresh seeds. Seed package container also had a significant effect of seed hardening treatment. Seeds preserved in the polythene bags supposed to less influence by the environmental factors whereas cloth bags influence much for long term jute seed preservation. Among the properties of healthy seeds, oil content has positive impact on seed viability as there exists positive relationship between oil content and germination of jute seed implying that retention of oil content through mid storage seed hardening is crucial for maintaining viability of stored seed. 


\section{Acknowledgements}

This research did not receive any significant grant from any funding agencies in the public, commercial or not-for-profit sectors.

\section{Authors' contributions}

MNU, SMMA, MAS and MZT designed the experiment. MNU, SMMA and MZT conducted the experiments. MAHC and IJM analysed the data. MNU, SMMA, MAS and MZT wrote the manuscript. All authors read and approved the final manuscript.

\section{Conflict of interests}

Authors do not have any conflict of interests to declare.

\section{Supplementary file}

Fig. S1. Seed container of jute varieties (A) polyene bags and (B) cloth bags.

Fig. S2. Maximum and minimum temperature and relative humidity of the store at ambient condition.

Fig. S3. Relative humidity of the store at ambient condition.

\section{References}

1. Anderson JD. Physiological and biochemical differences in deteriorating barley seed. Crop Sci. 1970;10:36-39. https://doi.org/10.2135/cropsci1970.0011183X001000010014x

2. Pradhan BK, Badola HK. Effect of storage conditions and storage periods on seed germination in eleven populations of Swertia chirayita: a critically endangered medicinal herb in Himalaya. The Sci World J. 2012;2012:1-9. https://doi.org/10.1100/2012/128105

3. Sung JM. Lipid peroxidation and peroxide- scavenging in soybean seeds during ageing. Physiologia Plantarum 1996;97:85-89. https://doi.org/10.1111/j.13993054.1996.tb00482.x

4. Basra SMA, Ahmad N, Khan MM, Iqbal N, Cheema MA. Assessment of cotton seed deterioration during accelerated ageing. Seed Sci \& Technol. 2003;31:531-40.

5. Priestley DA, Leopold AC. Lipid changes during natural ageing of soybean seeds. Physiologia Planatarum. 1983;59:467-70. https://doi.org/10.1111/j.1399-3054.1983.tb04231.x

6. Pan D, Basu RN. Mid storage and pre-sowing seed treatment for lettuce and carrot. Scientia Hort. 1985;25:11-19. https://doi.org/10.1016/0304-4238(85)90072-X

7. Basu RN. An appraisal of research on wet and dry physiological seed treatments and their applicability with special reference to tropical and sub-tropical countries. Seed Sci \& Technol. 1994;22:107-26.

8. Haque SMA, Hossain I, Rahman MA. Effect of different storage containers used for storing seeds and management practices on seed quality and seed health in CVL-1 variety. Int J Plant Pathol. 2014;5(2):28-53. https://doi.org/10.3923/ijpp.2014.28.53

9. Gopa D, Mukherjee RK. Iodine treatment of soybean and sunflower seeds for controlling deterioration. Field Crop Res. 1984;9:205-13. https://doi.org/10.1016/0378-4290(84)90026-1

10. McDonald. Seed deterioration: physiology and assessment. Seed Sci \& Technol. 1999;27 (1):177-237.

11. Basu RN. Seed invigoration for extended storability. Proc Int conf on seed Sci \& Technol. New Delhi. 1990.

12. Basu RN, Mandal K. Viability of horticultural seeds and seed invigoration treatments vegetables and flowers. In: Propagation of Tropical and Subtropical Horticultural crops. T K Bose, SK Mitra, MK Sadhu (editors), Naya Prakash, Calcutta. 1986. P. 571-96.
13. Basu RN, Rudrapal AB. Post-harvest seed physiology and seed invigoration treatments. In: Proc Ind Stat Inst Gold Jubilee Int Conf. Frontiers of Res Agric. SK Roy (editor). 1982;374-97.

14. Islam MM. Jute seed technology, College gate binding and printing, Dhaka. 2009. p. 89-97.

15. Uddin MN, Haque MM, Ali SMM, Salam MA, Haque MN. Prestorage seed hardening effects on germination, vigour and seedling growth of jute species: Corchorus capsularis L. and Corchorus olitorius L. J Expt Agril Int. 2018;22(1):1-10. https://doi.org/10.9734/JEAI/2018/38817

16. Kazal MMH, Rahman S, Alam MJ, Hossain ST. Financial and economic profitability of selected agricultural crops in Bangladesh; NFPCSP-FAO Research Grant Report \#05/11; Food Planning and Monitoring Unit, Ministry of Food, Government of Bangladesh: Dhaka, Bangladesh. 2013.

17. Islam MM. Status and constraints of jute cultivation in Bangladesh: an experience from selected upazilas under Chandpur district. Asian J Agril Rural Deve. 2015;5(8):175-86.

18. Ali SM, Haque MM, Siddique AB, Mollah A., Islam MN. Phenology growth and seed yield of tossa jute (Corchorus olitorius L.) in late sown technology. Bangladesh J Agril. 2003;27 \& 28:91-97.

19. Ali SMM. Effect of nitrogen and phosphorus fertilizers on yield and physiological and biochemical quality of jute seed under field and storage conditions. Unpublished Ph.D. Thesis, Seed Science and Technology Unit, Bangabandhu Sheikh Mujibur Rahman Agricultural University, Gazipur, Bangladesh. 2011.

20. Sikder FS, Saha CK, Rahman M, Alam AKMM, Haque S. Jute production in Bangladesh- an overview. Abstracts of papers. International Symposium on Jute and Allied Fibres Production, Utilization and Marketing. National Library. Kolkata. India. 2008.

21. Krishnasamy V, Seshu DV. Germination after accelerated ageing and associated characters in rice varieties. Seed Sci \& Technol. 1990;18:147-57.

22. Bedi S, Kaur R, Sital JS, Kaur J. Artificial ageing of Brassica seeds of different maturity levels. Seed Sci \& Technol. 2006;34:287-96. https://doi.org/10.15258/sst.2006.34.2.04

23. Kalpana R, Rao KVM. Protein metabolism of seeds of pigeon pea cultivars during accelerated ageing. Seed Sci \& Technol 1997;25:271-79.

24. Lowry $\mathrm{OH}$, Rosebrough NRJ, Farr AL, Randail RJ. Protein measurement with the folin phenol reagent. J Biol Chem. 1951;193:265- 75 .

25. Moore S, Stein WH. Photometric methods for use in the chromatography of amino acids. J Bio Chem. 1948;176:367-88.

26. Shirlaw DW, Grlchrist DW. A practical course in agricultural chemistry. Pergamon Pub. London, U.K. 1967. P. 122-30.

27. Gadgil JD, Susseelan KN, Mitra R, Joshua DC, Bhatia CR. Chemical composition of seed and electrophoretic pattern of seed storage protein of jute Corchorus olitorius and Corchorus capsularis. Seed Sci \& Technol. 1989;17:499-506.

28. Delouche JC, Matthes RK, Dougherty MC. Storage of seed in subtropical and tropical regions. Seed Sci \& Technol. 1973;1:671-700.

29. Gupta A, Aneja KR. Seed deterioration in soybean varieties during storage - Physiological attributes. Seed Res. 2004;32:2632.

30. Copeland LO, McDonal MB. Principles of Seed Science and Technology, $4^{\text {th }}$ Edition, Springer (India) Pvt. Ltd. New Delhi, India. 2005

31. Freitas RA, Dias DCFS, Oliveira MGA, Dias LAS, Jose LC. Physiological and biochemical changes in naturally and artificially aged cotton seeds. Seed Sci \& Technol. 2006;34:25364. https://doi.org/10.15258/sst.2006.34.2.01

32. Basu RN, Chattopadhyay K, Pal P. Maintenance of seed viability of rice (Oryza sativa L.) and jute (Corchorus capsularis and $C$. olitorius L.). Indian Agril. 1974;18:75-79.

33. Roberts EH. Physiology of ageing and its application to drying and storage. Seed Sci \& Technol. 1981;9:359-72.

34. Osborne DJ. Deoxiribonucleic acid integrity and repair in seed germination: the importance in viability and survival. In: AA Khan (editor). The physiology and biochemistry of seed development, dormancy and germination. 1982. p. 435-63.

35. Agrawal PK. Genotypic variation in germination and membrane permeability in wheat (Triticum aestivum) seeds 
during storage under ambient condition. Seed Res. 1980;7:12027.

36. Kalpana R, Rao KVM. Absence of role of lipid peroxidation during accelerated ageing of seeds of pigeon pea (Cajanus cajan (L.) Millsp.) cultivars. Seed Sci \& Technol. 1994;22:253-60.

37. Wolkers WF, McCready S, Brandt WF, Lindsey GG, Hoekstra FA. Isolation and characterization of a D-7 LEA protein from pollen that stabilizes glasses in vitro. Biochimica et Biophysica Acta. 2001;1544:196-206. https://doi.org/10.1016/S01674838(00)00220-X

38. Raiker SD, Kulkarni GN, Shashidhar SD, Vyakarnahal BS, Basakar PW. Effect of delimiting, seed treatment and packaging material on the change of composition in cotton seed during storage. Karnataka J Agric Sci. 2006;19:24-26.

39. Basavarajappa BS, Shetty HS, Prakas HS. Membrane deterioration and other biochemical changes associated with accelerated aging of maize seeds. Seed Sci Res. 1991;19:279-86.

40. Sreeramulu N. Germination and food reserves in bambarra groundnut seeds (Foandzeia subterranea Thouars) after different periods of storage. J Exp Bot. 1983;34:27-33.

41. Baki AA, Anderson JD. Viability and leaching of sugars from germinating barley. Crop Sci. 1970;10:31-34 https://doi.org/10.2135/cropsci1970.0011183X001000010012x

42. Edje OT, Burris JS. Physiological and biochemical changes in deteriorating soybean seeds. Proc Assoc Off Seed Anal. 1970;60;158-166.

43. Petruzelli L, Taranto G. Wheat ageing: the contribution of embryonic and non-embryonic lesions to loss seed viability. Plant Physiol.1989;76:189-94. https://doi.org/10.1111/j.1399 3054.1989.tb06193.x

44. Bruni F, Leopold AC. Glass transitions in soybean seed: relevance to anhydrous biology. Plant Physiol. 1991;96:660-63. https://doi.org/10.1104/pp.96.2.660

45. Crowe LM, Mourdian R, Crowe JH, Jackson SA, Womersly C. Effects of carbohydrates on membrane stability at lower water activities. Biochem Biophys Acta.

1984;769:141-50 https://doi.org/10.1016/0005-2736(84)90017-8

46. Williams RJ, Leopold AC. The glassy state in corn embryos. Plant Physiol. https://doi.org/10.1104/pp.89.3.977 1991;89:977-81.

47. Cieslak Pal, Niedzielski M, Michalczyk DJ, Luczak W, Adomas B. Soluble carbohydrates in cereal (wheat, rye and triticale) seed after storage under accelerated ageing conditions. Acta Societatis Botanicorum Polaniae. 2010;79:21-25. https://doi.org/10.5586/asbp.2010.003

48. Donald DGM, Jacobs CB. The effect of storage time, temperature and container on the viability in the seeds of four pine species. South Afri J For. 1990;154:41-46. https://doi.org/10.1080/00382167.1990.9629050

49. Lugo BI, Leopold AC. Changes in soluble carbohydrates during seed storage. Plant Physiol. 1992;98:1207-10. https://doi.org/10.1104/pp.98.3.1207

50. Yap SK, Wang SM. Seed biology of Acacia mangium, Albizia falcataria, Eucalyptus spp., Gmelina arborea, Pinus caribaea and Tectona grandis. Malay For. 1983;46:26-45.

51. Feeney RE, Whitaker JR. The Maillard reaction and its prevention. In: JP Cherry (editor). Food Protein Deterioration: American Chemical Society Symposium No. 206. American Chemical Society, Washington. 1982. p. 201-30.

52. Raiker SD, Kulkarni GN, Shashidhar SD, Vyakarnahal BS, Basakar PW. Effect of delimiting, seed treatment and treatment and packaging material on the change of composition in cotton seed during storage. Karnataka J Agric Sci. 2006;19:24-26.

53. Wettlaufer SH, Leopold AC. Relevance of Amadori and Maillard reactions to seed deterioration. Plant Physiol. 1991;97:165-69.https://doi.org/10.1104/pp.97.1.165

54. Malik AR, Shamet GS. Storage of Pinus gerardiana seeds: Biochemical changes and its applicability as vigour test. Res Seed Sci. 2009;2:48-55. https://doi.org/10.3923/rjss.2009.48.55 